\title{
Ecology of colonizing populations of the figfly Zaprionus indianus (Diptera, Drosophilidae) in Porto Alegre, Southern Brazil
}

\author{
Norma Machado da Silva ${ }^{1}$, Carina da Conceição Fantinel $^{1}$, Vera Lucia da Silva Valente ${ }^{1} \&$ \\ Vitor Hugo Valiati ${ }^{1,2,3}$
}

\begin{abstract}
1. Departamento de Genética, Instituto de Biociências, Universidade Federal do Rio Grande do Sul, Av. Bento Gonçalves, 9500, Caixa Postal 15053, 91501-970 Porto Alegre, RS, Brasil. (normamsilva@yahoo.com.br)

2. Centro de Ciências da Saúde, Universidade Luterana do Brasil, Canoas, RS, Brasil.

3. Laboratório de Biologia Molecular, Universidade do Vale do Rio dos Sinos, Caixa Postal 275, 93022-000 São Leopoldo, RS, Brasil. (valiati@cirrus.unisinos.br)
\end{abstract}

\begin{abstract}
Ecological parameters such as trophic niche overlap and niche breadth were computed from the frequency of all drosophilid species collected in 2001 and 2002, in the urban area of Porto Alegre city, Brazil. Independently of place, drosophilids community composition and components breeding or feeding sites, the highest frequencies of Zaprionus indianus (Gupta, 1970) were obtained during seasons with higher average temperatures, especially during summer. From a total of the 19,146 individuals of Z. indianus sampled, $80 \%$ were found in this season. The data of trophic niche breadth suggest a higher opportunism of adult flies in feeding substrate use, but the females are still selective in oviposition substrate choice. For the values of niche overlap, only for some species, did we find any correlation between these and species richness and/or number of resources, and the most of the correlation values considering breeding and feeding sites were positive. The colonization of $Z$. indianus in Porto Alegre could be leading to adjustments in the survival strategies of the resident species, but it is possible that many species have conditions for coexisting with the invader.
\end{abstract}

KEYWORDS. Drosophilids, niche overlap, niche breadth.

RESUMO. Ecologia de populações colonizadoras da mosca-do-figo Zaprionus indianus (Diptera, Drosophilidae) em Porto Alegre, sul do Brasil. Parâmetros ecológicos tais como sobreposição e amplitude de nicho trófico foram aplicados a partir da frequiência de todas as espécies de drosofilídeos coletados em 2001 e 2002 na área urbana da cidade de Porto Alegre, Brasil. Independentemente do local, da composição da comunidade de drosofilídeos e dos componentes sítios de ovoposição e alimentação, as maiores frequiências de Zaprionus indianus (Gupta, 1970) foram obtidas durante as estações com médias de temperatura maiores, especialmente durante o verão. De um total de 19.146 indivíduos de Z. indianus amostrados, $80 \%$ foram coletados nesta estação. Os dados de amplitude de nicho trófico sugerem um maior oportunismo de moscas adultas no uso de substratos para alimentação, mas as fêmeas permanecem seletivas na escolha dos substratos para ovoposição. Para os valores de sobreposição de nicho, somente para algumas espécies, encontramos correlação entre estes e a riqueza de espécies e/ou número de recursos, e a maioria dos valores de correlação considerando sítios de ovoposição e alimentação foram positivos. A colonização de Z. indianus em Porto Alegre pode estar levando a ajustes nas estratégias de sobrevivência de espécies residentes, mas é possível que muitas espécies tenham condições de coexistir com a invasora.

PALAVRAS-CHAVE. Drosofilídeos, sobreposição de nicho, amplitude de nicho.

Invasive species occur in different taxonomic groups and can lead to diverse economic, social and biological implications. From the economic viewpoint, there is a financial cost because of the efforts to control the invader. Invasive species can cause damages to the rural sector when they reach pest status in commercial cultures. From the ecological viewpoint, the introduction into new environments can have huge consequences to the stability of native community. Invaders can not only alter competitive interactions and reduce native populations size in a community, but also eventually lead to extinctions. The number of individuals and species transported, even involuntarily, by human action across biogeographical barriers is presumably enormous. However, only a small fraction of the species transported is able to establish in the new territory, and among those, generally, $1 \%$ has the potential to become a pest (MOONEY \& Cleland, 2001).

The first published record of Zaprionus indianus (Gupta, 1970), an afrotropical species, for South America, refers to individuals observed on fruits of Diospyros kaki (L.; Ebenaceae) in the metropolitan area of the city of São Paulo (São Paulo state, Brazil), in March 1999 (VILELA, 1999a). In that same period, it was found feeding on the exotic fruit Alleurites mollucana (Euphorbiaceae), in the city of Florianópolis (Santa Catarina state, Brazil) (DE TONI et al., 2001).

The southernmost collection site on the American continent for this species was Montevideo city (Uruguay) in April of 2000, emerging from fruits of Butia yatai (Palmae) (GoÑ et al., 2001). Zaprionus indianus was found integrating drosophilid communities in the urban area of Porto Alegre city for first time in March 2000 (CAstro \& VALEnTE, 2001).

Zaprionus indianus has been popularly called the "figfly" because they use this fruit as breeding site. Since figs (Ficus carica L.; Moraceae) are commercial fruits, and this fly in Brazil uses the fruit while still on the tree, the fly is being considered a pest insect. Despite having been found on fruits of 74 species belonging to 31 plant families, to this moment, only on figs $Z$. indianus attacks at the beginning of fruit maturation, rendering it unwanted commercially. Nevertheless, in its place of origin, this species has not been considered as a pest (VILELA et al., 2001).

In spite of its abundance in tropical communities and the fact that this drosophilid is increasing in 
geographical distribution, probably due to the intensification of world commerce in fruits (VILELA et al., 2001), Zaprionus indianus is still not well studied. It is a polyphagous species, its larvae have been found developing in various kinds of decomposing fruits, commonly found in orchards (VILELA, 1999b), and also in urban environments as parks. These characteristics, associated to its oviposition ability in fruits in maturation stage, as is the case for figs, can represent an additional danger to other kinds of cultures, which would cause economic losses for orchard owners.

Damages to natural ecosystems must be taken into account when considering the use of chemical controls, with still largely unpredictable environmental consequences, especially due to the lack of knowledge on the population dynamics of the invasive species and the interaction with native communities (VILELA, 1999b). Thus, Zaprionus indianus can represent a potential threat to Neotropical drosophilids, and the knowledge on its population dynamics and adaptive strategies could offer subsidies to a better understanding of invasive species.

This work represents an attempt to describe some possible colonization strategies of this species, using ecological parameters such as trophic niche overlap and niche breadth and, consequently measuring the impact on other species of local communities of drosophilids in the urban area of the city of Porto Alegre. Drosophilids are ecologically important, the majority feeds fundamentally on bacteria and yeasts participating in the fermentation of carbohydrate-rich substrates, specially decomposing fruits (CARSON, 1971).

\section{MATERIAL AND METHODS}

Drosophilid flies were collected from three places in Porto Alegre city $\left(30^{\circ} 02^{\prime} \mathrm{S}, 5^{\circ} 14^{\prime} \mathrm{W}\right)$ with different urbanization levels (Farroupilha Park, high urbanization level; Botanical Gardens, medium level; and Gabriel Knijnik Park, low level) according to RuszCZYK (1986). Sampling was done during seven seasons, from February 2001 to September 2002, one sample per season for each place, always in the last of each season, in the period between 9 and 12 am.

Three sampling methods were employed: 1 . adult flies were netted as they were flying over a variety of available rotting fruits (Averrhoa carambola (L.) (Oxalidaceae); Butia eriospatha Becc. (Palmae); Syagrus romanzoffiana (Cham.) Glassmann (Arecaceae); Maclura pomifera (Raf.) C.K. Schneider (Moraceae); Psidium guajava (L.); Psidium araça Raddi (Myrtacea); Ficus sp. (L.) (Moraceae) and Hovenia dulcis Thunb. (Rhamnaceae), sampling the surroundings of each tree with fruits; 2 . during periods of low fruits availability at the places, conventional banana baits (in the ground) were employed (two points for each place and ten bananas for each point); 3. larval stages were collected from inside fermenting fruits from the field and kept in bottles containing vermiculite on controlled temperature and humidity conditions $\left(25^{\circ} \mathrm{C} \pm 1^{\circ} \mathrm{C}, 60 \%\right.$ R.H. $)$, in this case the same fruits number were collected of each place. Adult specimens were identified and counted following FREIREMAiA \& PAVAN (1949) and ChASSAGNARD \& TsACAS (1993) keys. The sibling species cryptic Drosophila melanogaster (Meigen, 1830) and D. simulans (Sturtevant, 1919), D. willistoni (Sturtevant, 1916) and D. paulistorum (Dobzhansky \& Pavan, 1949) were counted together as subgroups (melanogaster and willistoni, respectively).

Considering that Zaprionus indianus belongs to the armatus group, vittiger subgroup, which is composed by 13 cryptic species, we identified this species from samples of isofemale lineages (10 per population) established in the laboratory with individuals taken from the three sampling places. The identification was done based on the diagnostic characteristics of body colour pattern, number of spines on the femur of the first pair of legs and the structure and form of the male genitalia.

Niche breadth and niche overlap estimates were computed, considering feeding and breeding sites components: 1. Niche overlap (SCHOENER, 1970): $\mathrm{C}_{\text {ih }}=1-$ $1 / 2\left|\mathrm{p}_{\mathrm{ij}}-\mathrm{p}_{\mathrm{hj}}\right|$ where, $\mathrm{p}_{\mathrm{ij}}$ is the proportion of species $i$ in trophic resource $j$; and $\mathrm{p}_{\mathrm{hj}}$ is the proportion of species $h$ in resource $j ; \mathrm{C}_{\mathrm{ih}}$ indicates the degree of interaction between species while exploiting a common resource. 2 . Niche breadth (Levins, 1968): $\mathrm{B}_{\mathrm{i}}=\mathrm{S} 1 / \mathrm{n} \mathrm{Sp}_{\mathrm{ij}}{ }^{2}$ where, $\mathrm{p}_{\mathrm{ij}}$ is the proportion of the total number of individuals of species $i$ found in resource $j$; and $n$ is the number of trophic resources.

For niche overlap, the components, breeding and feeding sites, were evaluated and analyzed considering the relationships among all species; however, correlation analyses (SPEARMAN, 1904), using the software SPSS 10.0.1, between those values and species richness and number of resources, were done only for species that occurred at least on two seasons across the whole sampling period.

\section{RESULTS AND DISCUSSION}

All individuals of the isofemale lineages sampled were identified as Zaprionus indianus. This fact is according to the statement of VILELA (1999a) that only this species from this genus has invaded South America. However, a monitoring with frequent sampling across the continent would be fundamental in order to follow the expansion of this species, as well as the possible detection of other species of the genus.

Independently of place, drosophilid community composition and components breeding or feeding sites, the highest frequencies of $Z$. indianus were obtained during seasons with higher average temperatures (summer and spring). Eighty percent of the 19,146 individuals of $Z$. indianus sampled were found during the summers of 2001 and 2002 (Tab. I).

For some of the seasons and in some places, no drosophilids were found flying over fruits, or there were no fermenting fruits to be brought back to the laboratory. For the comparative analyses of niche breadth (using ANOVA), taking the feeding (Tab. II) and breeding (Tab. III) sites components, only situations where the same entities occurred together in all three places, on the same seasons, for both consecutive years were considered. Zaprionus indianus, subgroup willistoni and subgroup 
Table I. Seasonal frequency of individuals sampled during 2001 and 2002 in Porto Alegre city (D.an, Drosophila angustibucca (Duda, 1925); D.bc, D.bocainensis (Pavan \& Cunha, 1947); D.bd, D.bandeirantorum (Dobzhansky \& Pavan, 1943); D.bu, D.busckii (Coquillett, 1901); D.ca, D.cardinoides (Dobzhansky \& Pavan, 1943); D.fu, D.fumippennis (Duda, 1925); D.gr, D.griseolineata (Duda, 1927); D.hy, D.hydei (Sturtevant, 1921); D.im, D.immigrans (Sturtevant, 1921); D.ki, D.kikkawaii (Burla, 1954); D.mc, D.maculifrons (Duda, 1927); D.mg, D.mediosignata (Dobzhansky \& Pavan, 1943); D.mi, D.mediopicta (Frota-Pessoa, 1954); D.mr, D.mercatorum (Patterson \& Wheeler, 1942); D.ms, D.mediostriata (Duda, 1925); D.mu, D.mediopunctata (Dobzhansky \& Pavan, 1943); D.nc, D.neocardini (Streisinger, 1946); D.ne, D.nebulosa (Sturtevant, 1916); D.pl, D.pallidipennis (Dobzhansky \& Pavan, 1943); D.pm, D.polymorpha (Dobzhansky \& Pavan, 1943); D.ps, D.prosaltans (Duda, 1927); D.pu, D.pulchella (Sturtevant, 1916); D.zo, D.zottii (Vilela, 1983); me sg., melanogaster subgroup; wi sg., willistoni subgroup; Z.in, Zaprionus indianus (Gupta, 1970); Zyg, Zygothrica).

\begin{tabular}{|c|c|c|c|c|c|c|c|c|c|c|c|c|c|c|c|c|c|c|c|c|c|c|}
\hline \multirow[b]{3}{*}{ Spp } & \multicolumn{7}{|c|}{ Botanical Gardens } & \multicolumn{7}{|c|}{ Farroupilha Park } & \multicolumn{7}{|c|}{ Gabriel Knijnik Park } & \multirow[b]{3}{*}{ Total } \\
\hline & \multicolumn{4}{|c|}{2001} & \multicolumn{3}{|c|}{2002} & \multicolumn{4}{|c|}{2001} & \multicolumn{3}{|c|}{2002} & \multicolumn{4}{|c|}{2001} & \multicolumn{3}{|c|}{2002} & \\
\hline & $\mathrm{m}$ & ut & & & & $u_{\mathrm{u}}$ & & & & Win & & & Aut & & & ut & Win & $\mathrm{pr}$ & & Aut & & \\
\hline Z.in & 0.08 & 00 & 00 & & & & 00 & 10 & & 0.00 & 01 & 0.20 & 0.01 & & 10 & 0.03 & 0.00 & 0.01 & 0.14 & 0.00 & 0 & 19146 \\
\hline esg & & & & & & & & & & & & & & & & & & & & 00 & & \\
\hline$i \mathrm{sg}$ & 06 & 2 & 4 & & & & & & & & & & & & & & & & & & & \\
\hline pm & 01 & 1 & & & & & & & & & & & & & & & & & & & & \\
\hline$m r$ & 01 & 1 & 9 & & & & & & & & & & & & & & & & & & & 34 \\
\hline$c a$ & 02 & ( & 0 & & & & & & & & & & 3 & & & & 33 & & & 1 & & 26 \\
\hline ne & 22 & 0 & ) & & & & & & & & & & & & & & & & & & & \\
\hline . & & 0 & & & & & & & & & & & & & & & & & & & & \\
\hline$k i$ & & & & & & & & & & & & & & & & & & & & & & 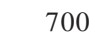 \\
\hline$m u$ & & & & & & & & & & & & & & & & & & & & & & 11 \\
\hline$m s$ & 00 & 0 & 02 & & & & & & & & & 08 & & & & & 01 & 1 & & & & 54 \\
\hline$m i$ & & & & & & & & & & & & 0 & & & & & & 3 & & & & 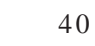 \\
\hline & & & & & & & & & & & & & & & & & & & & & & \\
\hline$i m$ & 0 & 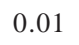 & 3 & ) & & & 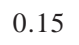 & 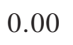 & 8 & 0 & 0 & 0 & 0 & & & 3 & 28 & 1 & 0 & 3 & & 51 \\
\hline$h d$ & 40 & 10 & 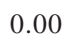 & 0 & & & 0 & & ) & 0.20 & 00 & 00 & 0.00 & & & & 0.00 & 0.00 & 0.00 & 0 & & 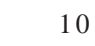 \\
\hline$m c$ & & & & & & & & & & & & & & & & 0 & 2 & & 0.01 & 33 & & 40 \\
\hline & & & & & & & & & & & & & & & & & & & & & & 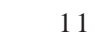 \\
\hline.$z o$ & & & & & & & & & & & & & & & & & 53 & & & & & 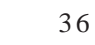 \\
\hline$f u$ & 00 & 00 & 00 & ) & & & ) & & 0 & 0.00 & 00 & 0.00 & 0.00 & & & & 0.00 & 0.00 & 0.00 & 0.00 & & \\
\hline D.pu & & & & & & & & & & & & & & & & & 00 & & & 0 & & 20 \\
\hline D.pl & & & & & & & & & & & 0.00 & & & & & & & & & 33 & & . \\
\hline 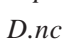 & & & & & & & & & & & & & & & & & 0.00 & & 0.00 & 0.94 & & \\
\hline 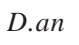 & 0.00 & 0.00 & 00 & 0 & 0 & 0 & 0 . & 0 & 0 & 0.00 & 0.00 & 0.00 & 0.14 & 0 . & 0 & 0 & 0.00 & 0.00 & 0.00 & 0.67 & & 21 \\
\hline & 0.00 & & & & & & & & & & & & & & & & & & 0 & 0 & & \\
\hline ny & 0.00 & 0.00 & 0 & 0 & & 0 & 0.00 & & 0 & 0.00 & 0.00 & 0 & 0.00 & 0 . & & 0.00 & 0.00 & 0.00 & 0.00 & 0.00 & & \\
\hline D.ps & 0.00 & 0.00 & 00 & & & & 0.00 & 00 & 0 & & 0.00 & 0.00 & 0.00 & 0 . & 0.00 & 0.00 & 1.00 & 0.00 & 0.00 & 0.00 & & \\
\hline & 0.00 & 0.00 & 00 & 00 & 0.00 & 0.00 & 0.00 & 00 & 0.00 & 0.00 & 0.00 & 0.00 & 0.00 & 0.00 & 0.00 & 0.00 & 0.00 & 0.00 & 0.00 & 1.00 & 0.00 & \\
\hline otal & 05 & 0.01 & 02 & 0.03 & 0.11 & 0.12 & 0.05 & 06 & 0.04 & 0.02 & 0.01 & 0.17 & 0.03 & 0.00 & 0.05 & 0.03 & 0.04 & 0.00 & 0.10 & 0.03 & 0.01 & 48609 \\
\hline
\end{tabular}

melanogaster, in general, were the most representative entities, appearing in practically all samples (Tab. I). When compared niche breadth values of these entities, from one summer to another, showed a significant increase $\left(\mathrm{F}_{5,12}=8.83, \mathrm{P}<0.001\right)$ on feeding site component, for the three places. Thus, these entities had an increase in available resource exploration and this pattern was similar for the three sampled places $\left(\mathrm{F}_{2,15}=0.98, \mathrm{P}=0.3988\right)$.

For the breeding site component it was possible to compare trophic niche breadth values between summers and autumns of 2001 and 2002 also for Zaprionus indianus, subgroup willistoni and subgroup melanogaster, for the three places. No significant increases were observed for trophic niche breadth values of these entities, neither between summers $\left(\mathrm{F}_{5,12}=0.44\right.$, $\mathrm{P}=0.8109)$, nor between autumns $\left(\mathrm{F}_{5,12}=2.31, \mathrm{P}=0.1088\right)$, for the three places. Equally, there were no differences in how the species use to oviposition resources among different places, when summers $\left(\mathrm{F}_{2,15}=3.54, \mathrm{P}=0.0549\right)$ and autumns $\left(\mathrm{F}_{2,15}=3.54, \mathrm{P}=0.0551\right)$ are compared.

These findings suggest that although there seems to be a trend for adult flies to become more opportunistic and feeding on a higher number of resources, females are still being selective in oviposition resource choice. Despite considering $D$. melanogaster and $D$. simulans as subgroup melanogaster and $D$. willistoni and $D$. paulistorum as subgroup willistoni, our previous experience (SAntos \& VALENTE, 1990; VALEnTE et al., 1989; Valiati \& VAlente, 1996, 1997) allows us to suppose that these subgroups correspond mostly to individual contributions from D. simulans and D. willistoni, respectively. Drosophila melanogaster, for example, is almost exclusively sampled in garbage cans and inside 
Table II. Trophic niche-breadth estimates (B; according to Levins, 1968) for drosophilid species collected in the urban area of Porto Alegre city, southern Brazil, in 2001 and 2002: feeding-site component (D.bc, Drosophila bocainensis; D.ca, D.cardinoides; D.fu, D.fumippennis; D.gr, D.griseolineata; D.hy, D.hydei; D.im, D.immigrans; D.ki, D.kikkawaii; D.mc, D.maculifrons; D.mi, D.mediopicta; D.mu, D.mediopunctata; D.mg, D.mediosignata; D.mr, D.mercatorum; D.ms, D.mediostriata; D. na, D. nappae Vilela, 2004; D.nc, D.neocardini; D.ne, D.nebulosa; D.pl, D.pallidipennis; D.pm, D.polymorpha; D.ps, D.prosaltans; D.pu, D.pulchella; me sg., melanogaster subgroup; wi sg., willistoni subgroup; Z.in, Zaprionus indianus; Zyg, Zygothrica).

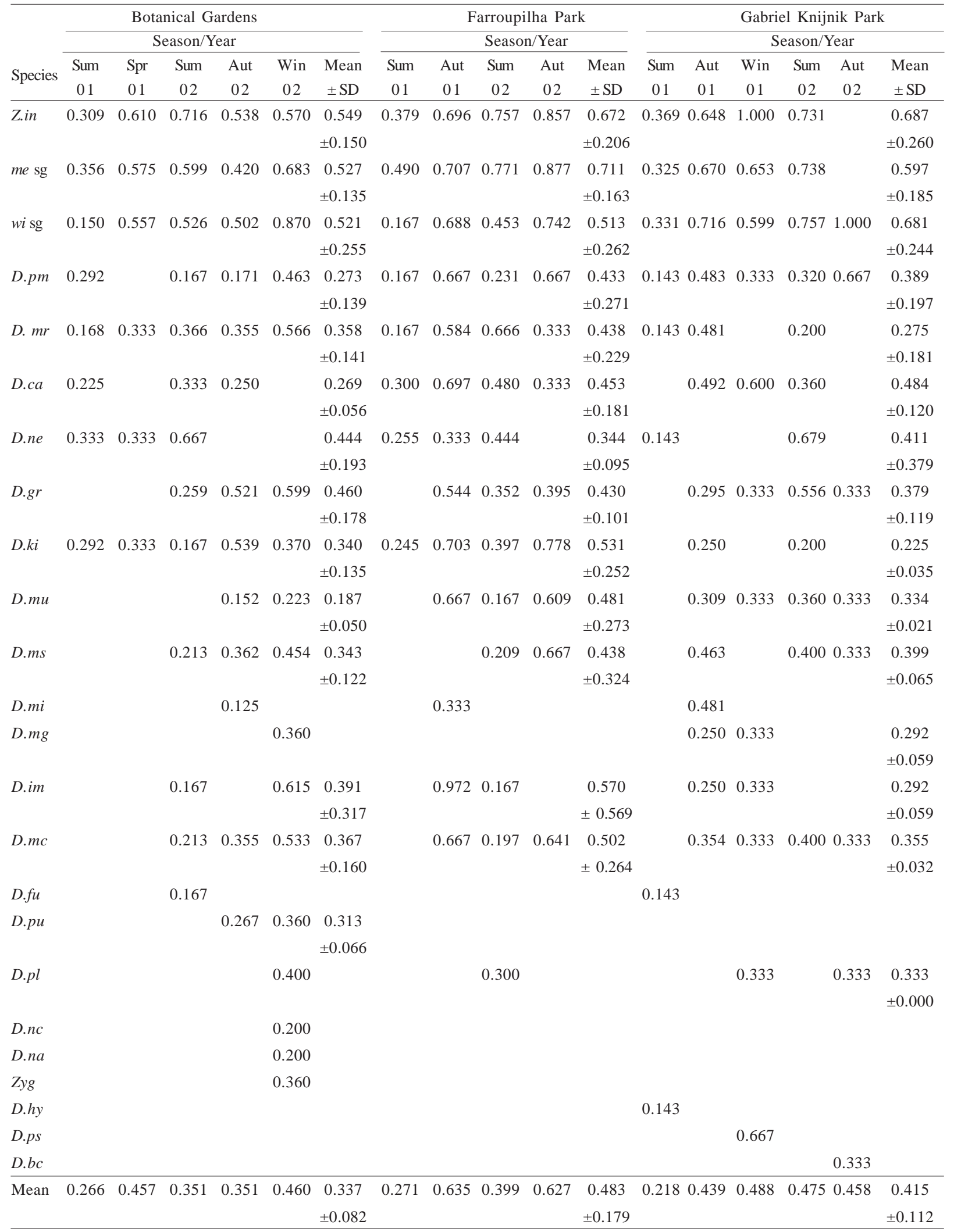


Table III. Trophic niche-breadth estimates (B; according to Levins, 1968) for drosophilid species collected in the urban area of Porto Alegre city, southern Brazil, in 2001 and 2002: breeding-site component (D.bd, Drosophila bandeirantorum; D.bu, D.busckii; D.ca, D.cardinoides; D.gr, D.griseolineata; D.hy, D.hydei; D.im, D.immigrans; D.ki, D.kikkawaii; D.mc, D.maculifrons; D.mi, D.mediopicta; D.mg, D.mediosignata; D.ms, D.mediostriata; D.mr, D.mercatorum; D.mu, D.mediopunctata; D.na, D. nappae; D.nc, D.neocardini; D.ne, D.nebulosa; D.pl, D.pallidipennis; D.pm, D.polymorpha; D.pu, D.pulchella; D.zo, D.zottii; me sg., melanogaster subgroup; wi sg., willistoni subgroup; Z.in, Zaprionus indianus).

\begin{tabular}{|c|c|c|c|c|c|c|c|c|c|c|c|c|c|c|c|c|c|c|}
\hline & & & tanical & 1 Garder & & & & & Farr & oupilha & a Park & & & & Gabriel & Knijnik & Park & \\
\hline & & & Season & $\mathrm{n} /$ Year & & & & & & eason/Y & Year & & & & Sea & son/Yea & & \\
\hline Specie & $\begin{array}{l}\text { Sum } \\
\text { s } 01\end{array}$ & $\begin{array}{c}\text { Aut } \\
01\end{array}$ & $\begin{array}{c}\text { Spr } \\
01\end{array}$ & $\begin{array}{c}\text { Sum } \\
02\end{array}$ & $\begin{array}{c}\text { Aut } \\
02\end{array}$ & $\begin{array}{c}\text { Win } \\
02\end{array}$ & $\begin{array}{c}\text { Mean } \\
\pm \mathrm{SD}\end{array}$ & $\begin{array}{c}\text { Sum } \\
01\end{array}$ & $\begin{array}{c}\text { Aut } \\
01\end{array}$ & $\begin{array}{c}\text { Sum } \\
02\end{array}$ & $\begin{array}{c}\text { Aut } \\
02\end{array}$ & $\begin{array}{c}\text { Mean } \\
\pm \text { SD }\end{array}$ & $\begin{array}{c}\text { Sum } \\
01\end{array}$ & $\begin{array}{c}\text { Aut } \\
01\end{array}$ & $\begin{array}{c}\text { Win } \\
01\end{array}$ & $\begin{array}{c}\text { Sum } \\
02\end{array}$ & $\begin{array}{c}\text { Aut } \\
02\end{array}$ & $\begin{array}{c}\text { Mean } \\
\pm \text { SD }\end{array}$ \\
\hline Z.in & 0.713 & 0.967 & 0.807 & 0.476 & 0.616 & 0.514 & $\begin{array}{c}0.682 \\
\pm 0.186\end{array}$ & 0.617 & 0.395 & 0.745 & 0.729 & $\begin{array}{c}0.622 \\
\pm 0.161\end{array}$ & 0.608 & 0.477 & 0.475 & 0.721 & 0.726 & $\begin{array}{c}0.601 \\
\pm 0.124\end{array}$ \\
\hline me sg & 0.566 & 0.603 & 0.342 & 0.683 & 0.474 & 0.646 & $\begin{array}{c}0.552 \\
\pm 0.126\end{array}$ & 0.428 & 0.414 & 0.585 & 0.660 & $\begin{array}{c}0.522 \\
\pm 0.120\end{array}$ & 0.477 & 0.549 & 0.736 & 0.247 & 0.482 & $\begin{array}{c}0.498 \\
\pm 0.175\end{array}$ \\
\hline wi sg & 0.310 & 0.966 & 0.777 & 0.509 & 0.889 & 0.575 & $\begin{array}{c}0.671 \\
\pm 0.250\end{array}$ & 0.419 & 0.377 & 0.614 & 0.889 & $\begin{array}{c}0.575 \\
\pm 0.234\end{array}$ & 0.468 & 0.876 & 0.729 & 0.533 & 0.828 & $\begin{array}{c}0.687 \\
\pm 0.180\end{array}$ \\
\hline D.pm & 0.125 & 0.533 & & & 0.542 & 0.696 & $\begin{array}{c}0.474 \\
\pm 0.244\end{array}$ & 0.410 & & & 0.623 & $\begin{array}{c}0.517 \\
\pm 0.151\end{array}$ & 0.125 & 0.450 & 0.761 & & 0.884 & $\begin{array}{c}0.555 \\
\pm 0.340\end{array}$ \\
\hline D.mr & 0.372 & 0.688 & 0.333 & 0.419 & 0.615 & 0.513 & $\begin{array}{c}0.490 \\
\pm 0.141\end{array}$ & 0.431 & 0.381 & 0.572 & 0.333 & $\begin{array}{c}0.429 \\
\pm 0.103\end{array}$ & & 0.430 & 0.637 & & 0.378 & $\begin{array}{c}0.482 \\
\pm 0.137\end{array}$ \\
\hline D.ca & & 0.333 & & & 0.225 & 0.200 & $\begin{array}{c}0.253 \\
\pm 0.071\end{array}$ & & 0.333 & 0.167 & 0.441 & $\begin{array}{c}0.314 \\
\pm 0.138\end{array}$ & 0.125 & 0.500 & 0.500 & & 0.533 & $\begin{array}{c}0.415 \\
\pm 0.194\end{array}$ \\
\hline D.ne & 0.125 & & & 0.167 & 0.125 & & $\begin{array}{c}0.139 \\
\pm 0.024\end{array}$ & 0.200 & 0.333 & & & $\begin{array}{c}0.267 \\
\pm 0.094\end{array}$ & 0.250 & & & & & \\
\hline D. $g r$ & & 0.333 & & 0.167 & 0.350 & 0.261 & $\begin{array}{c}0.278 \\
\pm 0.083\end{array}$ & & & & 0.610 & & & 0.250 & 0.333 & & 0.617 & $\begin{array}{c}0.400 \\
\pm 0.192\end{array}$ \\
\hline D. $k i$ & & 0.758 & 0.333 & 0.444 & 0.409 & & $\begin{array}{c}0.486 \\
\pm 0.187\end{array}$ & 0.360 & 0.509 & 0.167 & 0.982 & $\begin{array}{c}0.505 \\
\pm 0.348\end{array}$ & & & 0.758 & & & \\
\hline D.mu & & 0.399 & & & 0.250 & 0.200 & $\begin{array}{c}0.283 \\
\pm 0.104\end{array}$ & & & & 0.333 & & & 0.250 & 0.584 & & 0.633 & $\begin{array}{c}0.489 \\
\pm 0.208\end{array}$ \\
\hline D.ms & & & & & 0.446 & 0.200 & $\begin{array}{c}0.323 \\
\pm 0.174\end{array}$ & & 0.333 & & 0.379 & $\begin{array}{c}0.356 \\
\pm 0.033\end{array}$ & & 0.250 & 0.600 & & 0.898 & $\begin{array}{c}0.583 \\
\pm 0.324\end{array}$ \\
\hline D.mi & & & & & 0.125 & & & & & & & & & & 0.641 & & 0.653 & $\begin{array}{c}0.647 \\
\pm 0.008\end{array}$ \\
\hline D. $m g$ & & & & & & 0.200 & & & & & 0.333 & & & & 0.600 & & & \\
\hline D.im & & 0.653 & & & 0.225 & 0.763 & $\begin{array}{c}0.547 \\
\pm 0.284\end{array}$ & & 0.333 & & & & & 0.359 & 0.624 & & 0.456 & $\begin{array}{c}0.480 \\
\pm 0.134\end{array}$ \\
\hline$D . b d$ & 0.125 & 0.333 & & & & & $\begin{array}{c}0.229 \\
\pm 0.147\end{array}$ & 0.200 & & & & & & & & & & \\
\hline D.mc & & & & & 0.125 & & & & & & 0.333 & & & & & & 0.600 & \\
\hline D.bu & 0.225 & & & & & & & & & & & & 0.125 & & & & & \\
\hline D.zo & & 0.649 & & & & & & & & & & & & & 0.333 & & 0.333 & $\begin{array}{c}0.333 \\
\pm 0.000\end{array}$ \\
\hline D.pu & & & & & 0.247 & & & & & & & & & & & & & \\
\hline D.pl & & & & & & & & & & & & & & & 0.587 & & & \\
\hline D.nc & & & & & & 0.200 & & & & & & & & & & & 0.938 & \\
\hline D.na & & & & & & & & & & & 0.600 & & & & & & 0.333 & \\
\hline D.hy & & & & & & & & & & & & & 0.125 & & & & & \\
\hline $\begin{array}{l}\text { Mean } \\
\pm \mathrm{SD}\end{array}$ & 0.320 & 0.601 & 0.518 & 0.409 & 0.378 & 0.414 & $\begin{array}{c}0.440 \\
\pm 0.102\end{array}$ & 0.383 & 0.379 & 0.475 & 0.557 & $\begin{array}{r}0.449 \\
\pm 0.085\end{array}$ & 0.288 & 0.439 & 0.593 & 0.500 & $\begin{array}{r}0.619 \\
=\end{array}$ & $\begin{array}{r}0.488 \\
\pm 0.133\end{array}$ \\
\hline
\end{tabular}


residences, whilst $D$. simulans can be sampled in all kinds of environments with some degree of alteration as streets and parks. If this trend is confirmed it could be suggested that $D$. simulans and $D$. willistoni, the dominant species before the Z. indianus invasion (SANTOS \& VALENTE, 1990; Valiati \& VALENTE, 1996, 1997), would be widening their feeding niches as much as the invader. It remains to test, therefore, whether $Z$. indianus is as a good competitor in exploring the feeding substrates as a larva as it seems to be when in adult stage. This approach could provide data on the selectivity of $Z$. indianus females whilst ovipositing, since they could be using the resources indiscriminately but only part of the eggs would be reaching the adult stage.

SAAVEDRA et al. (1995), analyzing drosophilid communities in Rio Grande do Sul, southern Brazil, in general, found lower averages for trophic niche breadth at Turvo State Park $\left(27^{\circ} 20^{\prime} \mathrm{S}, 53^{\circ} 10^{\prime} \mathrm{W}\right)$ than those found for samples in Guaíba city ( $\left.30^{\circ} 05^{\prime} \mathrm{S}, 51^{\circ} 39^{\prime} \mathrm{W}\right)$, especially for feeding site. The authors suggest a higher species specialization in the Turvo area, since this place has a more preserved environment, with higher resource abundance accessible to the drosophilid community when compared to the Guaíba area community. VALENTE \& ARAúJo (1991), also analyzing drosophilid communities in Rio Grande do Sul, likewise found lower averages for trophic niche breadth values for Turvo State Park when compared with values for Itapuã State Park $\left(30^{\circ} 17^{\prime} S\right.$, $51^{\circ} 01$ ' $\mathrm{W}$ ), but specifically for breeding site. These papers concern comparisons among drosophilid communities from places that are inherently different, which does not apply to the present work. The places studied here are all urban parks, though Gabriel Knijnik Park is located in what is considered a low urbanization area. Even though having different dimensions and varied resources availability along the seasons, at least for $Z$. indianus the average values for trophic niche breadth do not seem to differ much among the three parks, despite the high values for the standard deviation, both for feeding and breeding sites. Zaprionus indianus seems to have been equally able to colonize all three places.

Regarding trophic niche overlap, only some species showed correlation between this value and species richness and/or resources number (Tabs. IV, V). The most of the correlation values considering breeding and feeding sites were positive (70\% with species richness and $83.3 \%$ with available resources number), that is, the increase in number of resources or in species richness was accompanied by an increase in values of niche overlap. Interestingly, the willistoni subgroup and Z. indianus had opposed sign correlations, that is, the willistoni subgroup had negative correlation with species richness in Farroupilha Park (for breeding site) and in Gabriel Knijnik Park (for both breeding and feeding sites) and a positive correlation with the resources number in all three places for the breeding site component. Zaprionus indianus had a positive correlation with species richness for all three places for both components, and a negative correlation with number of resources in Farroupilha Park for feeding site, and in Gabriel Knijnik Park for feeding and breeding sites. Positive correlations with the number of resources indicate that females are using the available resources in a similar way and consequently would be sharing those with the different species composing the local drosophilid fauna.

High values of niche overlap could be interpreted as leading to competition, especially when the breeding site component is considered. However, this competition would be reduced by oviposition on a large number of resources, but in lower frequencies. Oviposition

Table IV. Interval of trophic niche overlap: feeding-site component $\left(\mathrm{C}_{\mathrm{ih}}\right.$; according to ScHOENER, 1970) values only for drosophilid species that showed statistically significant correlations of these values with species richness $(S)$ and/or available resources number for the three places sampled, in 2001 and 2002 (sg, subgroup; *, p < 0.05; **, p < 0.01).

\begin{tabular}{|c|c|c|c|c|c|c|}
\hline \multirow{3}{*}{$\frac{\text { Local }}{\text { Botanical Gardens }}$} & \multirow{3}{*}{$\frac{\text { Species }}{\text { Z.indianus }}$} & \multirow{3}{*}{$\frac{\text { Interval }\left(\mathrm{C}_{\mathrm{ih}}\right)}{0.574-0.998}$} & \multirow{2}{*}{\multicolumn{2}{|c|}{$\frac{\mathrm{C}_{\mathrm{ih}}}{\mathrm{Mean} \pm \mathrm{SD}}$}} & \multicolumn{2}{|c|}{ Correlation Coefficient (r) } \\
\hline & & & & & \multirow{2}{*}{$\frac{S}{0.644 * *}$} & \multirow[t]{2}{*}{$\mathrm{N}^{0}$ resources } \\
\hline & & & 0.836 & 0.146 & & \\
\hline & D.nebulosa & $0.574-1.000$ & 0.948 & 0.100 & $0.365^{*}$ & \\
\hline & D.imigrans & $0.868-0.996$ & 0.944 & 0.025 & $0.398^{*}$ & $0.398 *$ \\
\hline & D. griseolineata & $0.656-1.000$ & 0.962 & 0.057 & & $0.300 *$ \\
\hline & D.maculifrons & $0.655-0.999$ & 0.965 & 0.065 & & $0.363^{*}$ \\
\hline \multirow[t]{5}{*}{ Farroupilha Park } & Z.indianus & $0.541-0.999$ & 0.885 & 0.131 & $0.572 * *$ & $-0.718 * *$ \\
\hline & D.cardinoides & $0.547-1.000$ & 0.959 & 0.072 & & $0.280 *$ \\
\hline & D.nebulosa & $0.550-1.000$ & 0.948 & 0.088 & & $0.322 *$ \\
\hline & D.imigrans & $0.801-1.000$ & 0.959 & 0.039 & $-0.325 *$ & $0.513 * *$ \\
\hline & D.griseolineata & $0.744-0.999$ & 0.911 & 0.073 & $0.319^{*}$ & $0.566^{* *}$ \\
\hline \multirow[t]{8}{*}{ Gabriel Knijnik Park } & Z.indianus & $0.578-1.000$ & 0.855 & 0.140 & $0.455 * *$ & $-0.666 * *$ \\
\hline & sg.willistoni & $0.601-1.000$ & 0.870 & 0.082 & $-0.682 * *$ & \\
\hline & D.cardinoides & $0.785-1.000$ & 0.959 & 0.065 & & $0.319^{*}$ \\
\hline & D.imigrans & $0.750-0.998$ & 0.955 & 0.051 & $0.364 *$ & $0.370 *$ \\
\hline & D.polymorpha & $0.578-1.000$ & 0.943 & 0.082 & & $0.528 * *$ \\
\hline & D. griseolineata & $0.726-1.000$ & 0.962 & 0.058 & & $0.351 *$ \\
\hline & D.mediopicta & $0.749-1.000$ & 0.954 & 0.056 & $0.495^{*}$ & $0.495 *$ \\
\hline & D.mediopunctata & $0.725-1.000$ & 0.944 & 0.133 & & $0.354 *$ \\
\hline
\end{tabular}


Table V. Interval of niche overlap: breeding-site component (C ; according to ScHoENER, 1970) values only for drosophilid species that showed statistically significant correlations of these values with species richness $(S)$ and/or available resources number for the three places sampled, in 2001 and 2002 (sg, subgroup; *, p < 0.05; **, p < 0.01).

\begin{tabular}{|c|c|c|c|c|c|c|}
\hline \multirow[b]{2}{*}{ Local } & \multirow[b]{2}{*}{ Species } & \multirow[b]{2}{*}{ Interval $\left(\mathrm{C}_{\mathrm{ih}}\right)$} & \multirow{2}{*}{\multicolumn{2}{|c|}{$\frac{\mathrm{C}_{\mathrm{ih}}}{\mathrm{Mean} \pm \mathrm{SD}}$}} & \multicolumn{2}{|c|}{ Correlation Coefficient $(r)$} \\
\hline & & & & & $S$ & $\mathrm{~N}^{0}$ resources \\
\hline \multirow[t]{6}{*}{ Botanical Gardens } & Z.indianus & $0.659-1.000$ & 0.889 & 0.112 & $0.738 * *$ & \\
\hline & sg. melanogaster & $0.772-0.979$ & 0.898 & 0.047 & $0.381 *$ & \\
\hline & sg. willistoni & $0.677-0.994$ & 0.868 & 0.070 & & $0.312 *$ \\
\hline & D.mercatorum & $0.669-0.997$ & 0.889 & 0.083 & $-0.427 * *$ & \\
\hline & D.imigrans & $0.737-1.000$ & 0.957 & 0.062 & $0.383 * *$ & $0.383 * *$ \\
\hline & D.griseolineata & $0.709-1.000$ & 0.954 & 0.075 & & $0.285 *$ \\
\hline \multirow[t]{3}{*}{ Farroupilha Park } & Z.indianus & $0.615-0.949$ & 0.805 & 0.096 & $0.798 * *$ & \\
\hline & sg. melanogaster & $0.623-1.000$ & 0.915 & 0.081 & $0.407 *$ & $-0.377 *$ \\
\hline & sg. willistoni & $0.623-1.000$ & 0.849 & 0.095 & $-0.544 * *$ & $0.324 *$ \\
\hline \multirow[t]{5}{*}{ Gabriel Knijnik Park } & Z.indianus & $0.569-1.000$ & 0.884 & 0.147 & $0.552 * *$ & $-0.795 * *$ \\
\hline & sg. willistoni & $0.587-0.985$ & 0.809 & 0.097 & $-0.540 * *$ & $0.290 *$ \\
\hline & D.polymorpha & $0.572-0.999$ & 0.928 & 0.085 & & $0.472 * *$ \\
\hline & D.mercatorum & $0.732-0.998$ & 0.948 & 0.060 & $-0.338 *$ & \\
\hline & D.imigrans & $0.688-0.999$ & 0.939 & 0.060 & & $0.409 * *$ \\
\hline
\end{tabular}

behaviour is an ecologically important trait in Drosophila melanogaster as the way in which the eggs are laid may have profound effects on the life expectancy of embryos (KAMPING \& DELDEN, 1990). Direct observations in nature have shown a variety of insertion behavior in flowerbreeding Drosophila species and in other Hawaiian Drosophilidae, reflecting specific adaptations to various oviposition resources (BRNCIC, 1983; KAMBYSELLIS \& HEED, 1971; PIPKIN et al., 1966).

Thus, the establishment of $Z$. indianus among the drosophilid species in Porto Alegre is probably leading to adjustments in the survival strategies of the resident species, in spite of the former's recent arrival in the city (CASTRO \& VALENTE, 2001). However, based on the results found for niche breadth, it is probable that many of the resident species are able to coexist with the invader. Besides this, some of the seasonal frequencies of the resident species did not change when compared to records from before the invasion. For example, $D$. mediopunctata (Dobzhansky \& Pavan, 1943) is more common in periods of lower temperatures (SAAVEDRA et al., 1995), which was also detected here. D. nebulosa (Sturtevant, 1916), a species with population peaks during periods of high temperature associated with low rainfall (BONORINO \& VALENTE, 1989), was more commonly found during hot seasons. For some drosophilid species, especially cosmopolitans ones as D. kikkawaii (Burla, 1954), climatic factors do not seem to be the most relevant and feeding and oviposition resource availability appear to determine abundance (VALENTE et al., 1989). Although Porto Alegre is in a subtropical climate region, the urban environment leads to the formation of "thermal islands" as a reflex of the urbanization process (DANNI, 1980), which interferes with plant fruit setting periods. In this manner, the impact of the arrival of an invader species affects the population of the native species differently. Nevertheless, the monitoring of the composition of the drosophilid communities at these places across time would allow an effective evaluation of the impact of the invasive species in the diversity and also to demonstrate which species would adapt to this new reality.

Acknowledgments. To Dr. Milton Mendonça Jr., of the Departamento de Zoologia, Instituto de Biociências, Universidade Federal do Rio Grande do Sul, for reviewing this manuscript. This research was supported by grants and fellowships from CNPq, CAPES, FAPERGS and PROPESQ-UFRGS.

\section{REFERENCES}

Bonorino, C. B. C. \& Valente, V. L. S. 1989. Studies on wild and urban populations and breeding sites of Drosophila nebulosa. Revista Brasileira de Biologia 49(3):771-776.

BRnCIC, D. 1983. Ecology of flower breeding Drosophila. In: Ashburner, M.; Carson, H. L. \& Thompson, J. JR., eds. The Genetics and Biology of Drosophila. New York, Academic Press. v. 3d, p.332-382.

Carson, H. L. 1971. The ecology of Drosophila breeding sites. Harold L. Lyon Arboretum Lecture, University of Hawaii Press. 28p.

Castro, F. L. \& Valente, V. L. S. 2001. Zaprionus indianus is invading Drosophilid communities in the southern Brazilian city of Porto Alegre. Drosophila Information Service 84:15-16.

Chassagnard, M. T. \& Tsacas, L. 1993. Le sous-genre Zaprionus s. str. définition de groupes d'espèces et révision du sousgroupe vittiger (Diptera, Drosophilidae). Annales de la Societe Entomologique de France (N.S.) 29(2):173-194.

DANNI, I. M. 1980. A ilha térmica de Porto Alegre: contribuição ao estudo do clima urbano. Boletim Gaúcho de Geografia 8:33-47.

De Toni, D. C.; Hofmann, P. R. P. \& Valente, V. L. S. 2001. First register of Zaprionus indianus (Diptera; Drosophilidae) in the state of Santa Catarina. Biotemas 14(1):71-85.

Freire-Maia, N. \& Pavan, C. 1949. Introdução ao estudo de Drosophila. Cultus 5(1):1-70.

Goñi, B.; Fresia, P.; Calviño, M.; Ferreiro, M. J.; Valente, V. L. S. \& Basso-Da-Silva, L. 2001. First record of Zaprionus indianus Gupta, 1970 (Diptera, Drosophilidae) in southern localities of Uruguay. Drosophila Information Service 84:61-64.

Kambysellis, M. P. \& Heed, W. B. 1971. Studies of oogenesis in natural populations of Drosophilidae. I. Relation of ovarian development and ecological habitats of the Hawaiian species. American Naturalist 105:31-49.

Kamping, A. \& van Delden, W. 1990. Genetic variation for 
oviposition behavior in Drosophila melanogaster. I. Quantitative genetic analysis of insertion behavior. Behavior Genetics 20(5):645-659.

Levins, R. 1968. Evolution in Changing Environments. Princeton, Princeton University Press. 120p.

Mooney, H. A. \& Cleland, E. E. 2001. The evolutionary impact of invasive species. Proceedings of the National Academy of Sciences 98(10):5446-5451.

PiPKIN, S. B.; RodrigueZ, R. L. \& LÉon, J. 1966. Plant host-specificity among flower breeding Neotropical Drosophila (Diptera: Drosophilidae). American Naturalist 100:135-156.

RuszczyK, A. 1986. Análise da cobertura vegetal da cidade de Porto Alegre, RS. Revista Brasileira de Botânica 9:225229.

SaAvedra, C. C. R.; Callegari-Jacques, S. M.; Napp, M. \& Valente, V.L.S. 1995. A descriptive and analytical study of four neotropical drosophilid communities. Journal of Zoology, Systematics and Evolutionary Research 33(2):62-74.

Santos, R. A. \& Valente, V. L. S. 1990. On the ocurrence of Drosophila paulistorum Dobzhansky \& Pavan (Diptera, Drosophilidae) in urban environment: ecological and cytological observations. Evolución Biologica 4:253-268.

Schoener, T. W. 1970. Nonsynchronous spatial overlap of lizards in patchy habitats. Ecology 51:408-418.

SpeARMAn, C. 1904. The proof and measurement of association between two things. American Journal of Psychology 15:72-101.
Valente, V. L. \& Araúso, A. M. 1991. Ecological aspects of Drosophila species in two contrasting environments in southern in Brazil (Diptera, Drosophilidae). Revista Brasileira de Entomologia 35(2):237-253

Valente, V. L. S.; Ruszczyk, A.; dos Santos, R. A.; Bonorino, C. B. C.; Brum, B. E. P.; Regner, L. \& Morales, N. B. 1989. Genetic and ecological studies on urban and marginal populations of Drosophila in the south of Brazil. Evolución Biologica 3:19-35.

Valiati, V. H. \& Valente, V. L. S. 1996. Observations on ecological parameters of urban populations of Drosophila paulistorum Dobzhansky \& Pavan (Diptera, Drosophilidae). Revista Brasileira de Entomologia 40(2):225-231.

1997. Chromosomal polymorphism in urban populations of Drosophila paulistorum. Brazilian Journal of Genetics 20(4):567-581.

Vilela, C. R. 1999a. Is Zaprionus indianus Gupta, 1970 (Diptera, Drosophilidae) currently colonizing the Neotropical region? Drosophila Information Service 82:37-39.

1999b. Nova praga nos figos: Zaprionus indianus Gupta, 1970. Informativo da Sociedade Entomológica do Brasil 24:2.

Vilela C. R.; Teixeira, E. P. \& Stein, C. P. 2001. Mosca-africanado-figo, Zaprionus indianus (Diptera, Drosophilidae). In: Vilela, E. F.; Zucchi , R. A. \& Cantor, F. eds. Histórico e Impacto das Pragas Introduzidas no Brasil. Ribeirão Preto, Holos. p. 48-52. 